\title{
OPINI PUBLIK TENTANG MALPRAKTEK KEDOKTERAN
}

\author{
Hardisman \\ Fakultas Kedokteran Universitas Andalas, Padang
}

\begin{abstract}
Background: In providing services, medical professionals have to be aware of social norms, ethics and lawe. Behaviors violate those regulations attract public attention and can lead to medical malpractice allegations. This study aimed to explore public opinion on medical malpractice, which was analyzed base on medical ethic principles.

Method: To answer the research question, descriptive and qualitative onlinesurvey bad been conducted from November 2009 to October 2010, which used structured and open-ended questionnaire. Theparticipants were obtained byemploying non-probability conveniencesampling. Later, the quantitative data was analyzed descriptively, and the qualitative data was analyzed thematically and presented narratively.

Results: In general, public opinion on malpractice is similar to the principles of medical ethics. They believe that rerong procedures, diagnosis and treatmentsarefactors of the malpractice. However, the participants adopt more consequentialism philosophy, whichemphasize on outcome of patients and lack of consideration what the doctors has done base on medical standards. More over, participants' explanations on medical malpractice reflect dissatisfaction of medical services which may due to low quality of information and attitude of doctors and other staffs in providingservices.

Conclusion: To improve public opinion on medical service and prevent medical malpractice allegation, doctors and otherstafs have to obey professional standardsandethics, providing adequate information and goodcommunication.
\end{abstract}

Keyrwords: medicalmalpractice, ethics, publicopinion.

\section{ABSTRAK}

Latar Belakang: Dalam menjalankan profesinya, dokter harus taat pada norma-norma sosial, etika profesi dan hukum. Pelanggaran akan nilai-nilai tersebut dapatmenjadi sorotanmasyarakat, dan bisa berlanjut kepada tuduhan malpraktek kedokteran. Penelitian ini dilakukan untuk menilai opini masyarakat tentang malpraktek kedokteran yang dianalisis berdasarkan prinsip-prinsip etika kedokteran.

Metode: Untuk menjawab tujuan penelitian ini telah dilakukan online survei deskriptif dan kualitatif pada bulan November 2009-Oktober 2010, dengan menggunakan kuesioner terstruktur dan pertanyaan terbuka. Responden didapatkan dengan teknik sampling non-probabilitas convenience sampling. Data dianalisis menggunakan prinsip-prinsip etika kedokteran secara deskriptif. Data kualitatif juga dilakukan analisa tematik serta ditampilkan dalam bentuk narasi.

Hasil: Secara umum opini masyarakat tentang malpraktek kedokteran sesuai dengan pandangan prinsip-prinsip etika kedokteran. Masyarakat berpendapat bahwa terjadinya malpraktek ada unsur kesalahan prosedur atau diagnosis dan penatalaksanaan. Namun, mereka cenderung pada filosofis konsekuentialis yang lebih menitikberatkan kepada akibat yang dialami oleh pasien yang kurang mempertimbangkan apa yang telah dilakukan dokter berdasarkan standar medis. Bahkan, ungkapan responden yang dianggapnya sebagai malpraktek lebih disebabkan karena ketidakpuasannya terhadap pelayanan yang diberikan. Ketidakpuasan tersebut timbul akibat rendahnya kualitas informasi dan sikap komunikasi dokter dan petugas dalam melakukan pelayanan.

Kesimpulan: Untuk memperbaiki opini masyarakat dan mencegah berbagai tuduhan malpraktek, dokter dan petugas kesehatan harus mentaati etika dan standar profesi dalam melakukan pelayanan, serta memberikan informasi yang cukup dan komunikasi yang baik dengan pasien.

Kata kunci: malpraktek kedokteran, etika, dan opini masyarakat

Korespondensi: hardisman@gmail.com, hardisman@fk.unand.ac.id 


\section{PENDAHULUAN}

Dalam menjalankan profesinya, dokter harus berpedoman pada standar dan etika profesi. Etika kedokteran tersebut merupakan salah satu aplikasi dari filosofi etika. Oleh karena itu, teori-teori filosofi etika menjadi landasan berpijak dari etika kedokteran, yaitu consequantialism (konsekuentialisme), deontologism (deontologisme) dan virtues of ethics (virtue etik). ${ }^{14}$

Konsekuentialis menilai baik buruk suatu perbuatan berdasarkan akibat dari perbuatan itu, bukan berdasarkan proses atau prosedur tindakan yang dilakukan. Berdasarkan sudut pandang konsekuantialis, suatu tindakan dikatakan salah jika efek yang ditimbulkannya adalah buruk. Sebaliknya, deontologis melihat baik buruknya suatu perbuatan berdasarkan prosedur atau proses perbuatan tersebut. Dalam menilai benar atau salah suatu tindakan medis, deontologis berpijak pada standar profesi baku dari pada kondisi pasien akibat tindakan tersebut. Sedangkan virtuis menilai bahwa baik buruknya suatu tindakan dinilai berdasarkan nurani atau niat dari si pelaku. Dalam hal ini, meskipun sulit dinilai, virtuis akan menilai suatu tindakan tersebut adalah salah jika niat dan tujuan si pelaku melakukannya adalah untuk kejahatan, meskipun yang ia lakukan sesuai dengan prosedur yang benar dan akhirnya tidak menimbulkan dampak negatif. ${ }^{14}$ Landasan filosofis ini perlu dimengerti untuk menilai dan menganalisis pandangan masyarakat nantinya terhadap tindakan medis. Selain itu, oleh karena landasan filosofis dalam prakteknya selalu terkait satu sama lain dalam menilai suatu tindakan medis yang diterapkan kasus per-kasus atau bahkan sesuai norma dan hukum dimana kasus itu terjadi. ${ }^{5,6}$

Etika kedokteran dan kode etik profesi medis didasarkan atas prinsip-prinsip beneficence/ non-maleficence (memberikan manfaat/ dan tidak memperburuk keadaan), respect for the autonomy (menghormati hak-hak pasien), justice (keadilan) dan personal integrity (integritas pribadi tenaga medis). ${ }^{6,7}$ Perilaku yang bertentangan dengan prinsip-prinsip tersebut merupakan suatu malpraktek kedokteran. ${ }^{6,7}$

Di Indonesia, masyarakat mulai mengkritisi dan memberikan perhatian serius terhadap perilaku dan tindakan profesional tenaga kesehatan. Masyarakat meningkat kesadarannya akan hak-haknya sebagai pasien saat mendapatkan pelayanan kesehatan, khususnya sejak dikeluarkannya Undang-Undang No.29 tahun 2004 tentang Praktek Kedokteran. ${ }^{8}$ Dengan merujuk pada UU tersebut, masyarakat makin sadar bahwa dokter dapat dituntut ke pengadilan bila dicurigai melakukan tindakan yang melanggar etika atau hukum. ${ }^{9}$ Tentunya, bila kesadaran akan hak dan tuntutan yang berlebihan tersebut bila tidak diiringi dengan pemahaman yang cukup tentang sistem dan kondisi pelayanan kesehatan, maka ketidakpuasan akan pelayanan kesehatan dengan mudah memberikan tuduhan malpraktek.

Penelitian ini dilakukan untuk menilai bagaimana opini atau pandangan masyarakat tentang malpraktek kedokteran, yang dianalisis dengan menggunakan prinsip-prinsip etika kedokteran.

\section{METODE}

Penelitian ini dilakukan pada bulan November 2009 sampai dengan Oktober 2010. Metode pengumpulan data pada penelitian ini adalah survei online, dengan fasilitas eSurveysPro dan menggunakan kuesioner sebagai instrumen pengumpulan data. Penelitian ini bersifat deskriptif dan kualitatif, yang mana sebagian data-data yang dikumpulkan bersifat kualitatif, dengan menggunakan pertanyaan terbuka sehingga responden bisa mengemukakan pendapatnya secara bebas dan terbuka terhadap isu yang ditanyakan, dan tidak dibatasi pada isian atau skala tertentu.

Responden penelitian didapatkan dengan menggunakan sampling non-probabilitas convenience sampling, yakni kesediaan responden secara sukarela untuk berpartisipasi dalam penelitian ini. Responden diundang untuk berpartisipasi pada penelitian ini melalui email langsung dan mailing list.

Alasan menggunakan metode survei online dan metode sampling non-probabilitas convenience sampling adalah untuk mendapatkan cakupan yang lebih luas di seluruh Indonesia. Selain itu, karena sifat data yang diharapkan adalah opini atau pendapat terbuka, sehingga reponden yang mau berpartisipasi 
pada penelitian ini adalah mereka yang mau memberikan pendapat mereka tentang isu yang ditanyakan. Pertimbangan etika suatu penelitian juga menjadi alasan dipilihnya metode ini, karena untuk memberikan respon pada suatu penelitian sosio-medis, seharusnya reponden

memberikan persetujuan dan tanpa paksaan. Dengan menggunakan metode ini, syarat etika penelitian terpenuhi.

Sebelum dilakukan pengolahan data, respon yang akan diolah harus memenuhi syarat untuk dilakukan pengolahan data, yaitu pengisian data lengkap dan tidak terjadi pengisian ganda (yang ditandai dengan identitas responden dan IP address komputer yang sama). Selain itu, untuk menghindari bias opini masyarakat, responden yang berprofesi sebagai dokter juga dieksklusi dari pengolahan data.

Selanjutnya data kuantitatif dianalisis secara deskriptif, sedangkan data kualitatif dilakukan analisis tematik. Data kuat pendukung juga ditampilkan dalam bentuk narasi. Data dianalisis dengan menggunakan pendekatan prinsip-prinsip etika kedokteran.

\section{HASIL DAN PEMBAHASAN}

Didapatkan 146 responden yang memenuhi syarat untuk diolah datanya. Responden penelitian ini tersebar hampir pada semua wilayah Indonesia, seperti di Jakarta, kota-kota di Pulau Jawa, Sumatera, Kalimantan, Sulawesi, Bali dan Nusa Tenggara, Kepulauan Maluku dan Papua dan ada juga yang berada di luar negeri.

Tabel 1. Karakteristik responden

\begin{tabular}{|c|c|c|c|}
\hline & \multirow{2}{*}{ Variabel } & \multicolumn{2}{|c|}{ Jumlah ( $n=146)$} \\
\hline & & f & $\%$ \\
\hline \multirow{6}{*}{ Umur } & $<25$ & 0 & $0,00 \%$ \\
\hline & $25-30$ & 32 & $21,92 \%$ \\
\hline & $>30-35$ & 51 & $34,93 \%$ \\
\hline & $>35-40$ & 38 & $26,03 \%$ \\
\hline & $>40.45$ & 16 & $10,96 \%$ \\
\hline & $>45$ & 9 & $6,16 \%$ \\
\hline \multirow[t]{2}{*}{ Jenis Kelamin } & Laki-Laki & 83 & $56,85 \%$ \\
\hline & Perempuan & 63 & $43,15 \%$ \\
\hline \multirow{9}{*}{ Profesi } & Dosen & 91 & $62,32 \%$ \\
\hline & $\begin{array}{l}\text { Pegawai Negeri Sipil (Non Guru/ } \\
\text { Dosen) }\end{array}$ & 30 & $20,54 \%$ \\
\hline & Guru & 5 & $3,43 \%$ \\
\hline & Pegawai BUMN & 5 & $3,43 \%$ \\
\hline & Pegawai Perusahaan Swasta & 5 & $3,43 \%$ \\
\hline & Praktisi: Hukum atau Akuntan & 3 & $2,05 \%$ \\
\hline & Pegawai/ Aktifis LSM & 2 & $1,37 \%$ \\
\hline & Swasta Mandiri/ Wirausahawan & 1 & $0,68 \%$ \\
\hline & Lain-lain & 4 & $2,74 \%$ \\
\hline
\end{tabular}

Responden berusia dari 25 hingga diatas 45 tahun, yang terbanyak berkisar $>30-35$ tahun (34,93\%). Distribusi gender responden terdiri dari 56,85\% lakilaki dan 43,15\% perempuan. Sedangkan profesi responden terbanyak adalah dosen $(62,32 \%)$ dan PNS
Non-Guru/ Dosen (20,54\%), seperti yang dapat dilihat pada Tabel 1 .

Dari total 146 responden tersebut, 138 (94,5\%) merasa tahu tentang apa yang dimaksud dengan malpraktek kedokteran. Dari 138 responden tersebut, 84,05\% 
mengemukakan bahwa mereka mendapat pengetahuan tentang malpraktek dari media massa (Tabel 2). Berdasarkan informasi yang didapatnya di media massa tersebut, umumnya $(81,16 \%)$ responden berpendapat bahwa malpraktek cukup banyak terjadi.

Tabel 2. Sumber informasi tentang malpraktek kedokteran

\begin{tabular}{lcc}
\multicolumn{1}{c}{ Sumber Informasi } & \multicolumn{2}{c}{ Jumlah } \\
& $\mathbf{f}$ & $\%$ \\
\hline Media Massa & 116 & $84,06 \%$ \\
\hline Pclajaran Sckolah/ Pcrkuliahan & 10 & $7,25 \%$ \\
\hline Orang I ain (teman, saudara, dan lain-lain) & 6 & $4,35 \%$ \\
\hline $\begin{array}{l}\text { Bacaan lainnya (bukan media massa dan bukan bagian pelajaran } \\
\text { sekolah) }\end{array}$ & 5 & $3,62 \%$ \\
\hline Lainnya & 1 & $0,72 \%$ \\
\hline Jumlah & 138 & $100 \%$ \\
\hline
\end{tabular}

Secara umum responden berpendapat bahwa malpraktek kedokteran merupakan kesalahan yang dilakukan oleh dokter sehingga berakibat buruk bagi pasien. Sebagaimana halnya responden mengungkapkan, bahwa malpraktek kedokteran adalah:

"Adanya upaya dari tenaga medis yang mengadakan kegiatan praktek kedokteran yang tidak sesuai dengan ketentuan-ketentuan yang diatur di dalam etika kedokteran, termasuk demi untuk memperoleh uang semata tanpa memikirkan risiko dan akibat yang terburuk bagi pasien”. (R1)

Beberapa aspek tematik yang sering diungkapkan oleh responden yang disebut sebagai malpraktek adalah mengakibatkan kondisi pasien bertambah buruk, kecacatan atau fatal $(34,06 \%)$, seperti terlihat pada Tabel 3 .

Responden juga menilai bahwa malpraktek kedokteran ada unsur kesalahan prosedur dalam pengobatan $(22,63 \%)$, tidak sesuai $\operatorname{SOP}(22,46 \%)$ ataupun kesalahan dalam diagnosis dan pemeriksaan (16,67\%). Sebagaimana beberapa responden menerangkan:

"Kesalahan yang dilakukan oleh tenaga paramedis, baik dokter atau perawat dalam menangani pasien,misalnya kesalahan pemberian suntikan dan dosis obat". (R78)
"Salah diagnosis dan salah ambil tindakan karena kecerobohan dokter/ perawat". (R126)

Akan tetapi responden menitikberatkan kepada kondisi akhir pasien tanpa adanya penjelasan mengenai riwayat dan perjalanan penyakitnya. Responden menilai apa yang dipahaminya sebagai malpraktek kedokteran berdasarkan akibat yang dialami oleh pasien, tanpa melihat tindakan yang telah dilakukan dokter. Bahkan beberapa responden menegaskan, bahwa malpraktek adalah:

"Kesalahan dalam penanganan pasien yang sakit sehingga pasien semakin parah atau meninggal dunia. Kesalahan ini tentunya tidak disengaja kalau disengaja bukan malpraktek [namanya], tapi penganiayaan”. (R3)

"Tindakan dokter yang semula dimaksudkan untuk menyembuhkan suatu penyakit, tetapi ternyata mengakibatkan penyakit tersebut tambah parah atau timbul penyakit lain”. (R66)

"Keadaan dimana penyakit yang dialami seorang pasien menjadi semakin parah atau bahkan pasien tersebut meninggal akibat kesalahan pihak rumah sakit atau dokter dalam memberikan penanganan atau diagnosis terhadap penyakit tersebut". (R136)

Meskipun responden menilai bahwa malpraktek kedokteran ada unsur kesalahan prosedur atau 
pengobatan, tetapi yang selalu dititik beratkan adalah kondisi pasien yang menjadi lebih buruk. Sebagaimana yang lainnya mengungkapkan:

"Kesalahan tindakan ataupun prosedur yang dilakukan dokter/ tim dokter/para medis/ rumah sakit terhadap pasien, yang merugikan pasien yang sering berdampak fatal seperti cacat permanen pada pasien atau malah meninggal dunia”. (R18)

"Kesalahan prosedur dan atau tindakan medis yang dilakukan oleh seorang dokter terhadap pasiennya yang berefek buruk terhadap pasiennya”. (R133)

Tabel 3. Opini responden tentang malpraktek

\begin{tabular}{|c|c|c|c|}
\hline & \multirow{2}{*}{ Tema } & \multicolumn{2}{|c|}{ Jumlah (n=138) } \\
\hline & & f & $\%$ \\
\hline \multirow{5}{*}{$\begin{array}{l}\text { Dilihat dari Aspek } \\
\text { Pasien }\end{array}$} & Risiko buruk pasien, kecacatan atau kematian & 47 & $34,06 \%$ \\
\hline & Tidak menghargai hak-hak pasien & 3 & $2,17 \%$ \\
\hline & Penanganan tidak dengan persetujuan & 2 & $1,45 \%$ \\
\hline & $\begin{array}{l}\text { Tidak mendapatkan penjelasan tentang alternatif } \\
\text { pengobatan }\end{array}$ & 1 & $0,72 \%$ \\
\hline & $\begin{array}{l}\text { Tidak mendapat penjelasan tentang risiko } \\
\text { pengobatan/ tindakan }\end{array}$ & 1 & $0,72 \%$ \\
\hline \multirow{5}{*}{$\begin{array}{c}\text { Dilihat dari Aspek } \\
\text { Dokter/ Tenaga Medis }\end{array}$} & Tidak sesuai ketentuan etika kedokteran & 22 & $15,95 \%$ \\
\hline & $\begin{array}{l}\text { Penanganan diluar atau tidak sesuai bidang } \\
\text { keahlian }\end{array}$ & 16 & $11,59 \%$ \\
\hline & Kurang teliti dan hati-hati atau kelalaian (careless) & 14 & $10,14 \%$ \\
\hline & Mengharapkan keuntungan semata atau finansial & 9 & $6,52 \%$ \\
\hline & $\begin{array}{l}\text { Tindakan ilegal (melawan hıkım)/ } \\
\text { penyalahgunaan profesi }\end{array}$ & 5 & $3,62 \%$ \\
\hline \multirow{5}{*}{$\begin{array}{l}\text { Dilihat dari Proses } \\
\text { Tindakan }\end{array}$} & Kesalahan pengobatan atau penatalaksanaan & 34 & $22,63 \%$ \\
\hline & Kesalahan prosedur atau tidak sesuai $\mathrm{SOP}$ & 31 & $22,46 \%$ \\
\hline & Kesalahan pemeriksaan atau diagnosis & 23 & $16,67 \%$ \\
\hline & Tindakan coba-coba & 3 & $2,17 \%$ \\
\hline & Kesalahan administratif & 1 & $0.72 \%$ \\
\hline
\end{tabular}

Berdasarkan pemahaman responden mengenai apa yang dimaksud dengan malpraktek kedokteran, sebanyak 33 responden $(23,91 \%)$ mengaku pernah menjadi pihak korban dari malpraktek kedokteran, baik yang dialami sendiri ataupun yang dialami keluarganya. Bentuk pengalaman terbanyak yang dianggap sebagai malpraktek oleh responden secara tematik adalah kondisi pasien menjadi lebih buruk setelah pengobatan (21,21\%), kesalahan diagnosis (15,15\%), dan kesalahan pemberian obat (15,15\%). Kasus-kasus lain, meskipun tidak banyak dilaporkan responden juga harus menjadi perhatian misalnya kelengkapan alat atau bahan medis untuk melakukan tindakan, tindakan tanpa persetujuan dan bahan atau alat kedokteran yang tertinggal setelah tindakan, data selengkapnya dapat dilihat pada Tabel 4 .

Sebagian besar pengalaman yang dimaksud dengan malpraktek lebih menitikberatkan pada rasa tidak puas akibat pelayanan dan kondisi memburuk setelah dilakukan pengobatan atau penatalaksanaan. Tidak jarang ungkapan responden tersebut jelas terlihat 
ketidakmengertiannya tentang penyakit yang diderita dan pelayanan yang dilakukan sehingga sebagai ungkapan ketidakpuasan tersebut mengatakan kasus yang dialaminya merupakan malpraktek, misalnya:

"Mertua saya sakit komplikasi jantung dan diabetes. Dokter selalu memberi obat yang reaksi obatnya hanya menghilangkan rasa sakit dan pemberian obat yang membuat ketergantungan. Akibatnya membuat organ tubuh lain diserang penyakit yaitu ginjal". (RP2)

"Anggota keluarga yang kena kanker payudara yang harus menjalani kemoterapi setelah operasi di salah satu RS di kota P. Pada kemoterapi pertama, langsung dilakukan oleh perawat yang didampingi oleh dokter bedah tersebut tapi pada saat kemo yang kedua tidak didampingi oleh dokter bedah tersebut, maka terjadinya kerusakan jaringan sel di lengan tempat penyuntikan kemo tersebut sehingga kulit dan daging di lengan tersebut hangus seperti kebakar, setelah komplain ke dokter tersebut hanya diberi obat dan tidak ada pertanggungjawaban dokter tersebut begitu juga RS tempat melakukan kemo. Pada kemo yang ketiga, juga didampingi oleh dokter tersebut dan terjadi juga seperti yang ke dua yang sampai akhirnya lengan tersebut lama kelamaan dagingnya mulai habis dan mengeluarkan bau yang tidak sedap". (RP7)

"Ayah saya terkena tumor usus besar sehingga harus dilakukan operasi untuk memotong tumor yang sepanjang $10 \mathrm{~cm}$ dari usus besar hingga anus. Operasi berjalan lancar dan dilanjutkan kemoterapi, namun kemudian urat saraf yang berhubungan dengan testis mungkin terpotong, kenyataannya ayah saya kemudian tidak dapat ereksi dan tidak dapat berhubungan badan, hal ini akhirnya mengakibatkan ayah saya patah semangat, dan kini ayah saya menderita stroke". (RP8)

Tabel 4. Bentuk-bentuk kasus malpraktek menurut pengalaman responden

\begin{tabular}{llc} 
& \multicolumn{1}{c}{ Kasus } & Jumlah (n=33) \\
\cline { 2 - 3 } & $\mathbf{f}$ & $\%$ \\
Kondisi pasien menjadi lebih buru k setelah pengobatan & 7 & $21,21 \%$ \\
\hline Kesalahan diagnosis & 5 & $15,15 \%$ \\
\hline Salah pemberian obat & 5 & $15,15 \%$ \\
\hline Pananganan tidak sesuai keahlian & 3 & $9,09 \%$ \\
\hline Efek samping berat tindakan infasif/ operasi & 2 & $6,06 \%$ \\
\hline Kondisi fatal atau kematian setelah tindakan/ pengobatan & 2 & $6,06 \%$ \\
\hline Dokter tidak memberikan atensi yang cukup (kurang cermat, & 2 & $6,06 \%$ \\
tidak hati-hati atau tidak teliti). & & \\
\hline Efek samping obat yang sangat jelek & 2 & $6,06 \%$ \\
\hline Informasi yang dibcrikan doktcr mempcrsulit kcadaan & 2 & $6,06 \%$ \\
\hline Terlambat penanganan & 1 & $3,03 \%$ \\
\hline Dirawat tanpa persetujuan & 1 & $3,03 \%$ \\
\hline Peralatan atau obat yang dibutuhkan pasien tidak siap/ tidak & 1 & $3,03 \%$ \\
tersedia & & $3,03 \%$ \\
\hline Bahan/ alat tertinggal setelah operasi/ tindakan & 1 & $3,03 \%$ \\
\hline Dokter kurang cakap, kurang ilmu, seperti tidak tahu & 1 & $3,03 \%$ \\
\hline Penatalaksanaan tidak tuntas & 1 & $3,03 \%$ \\
\hline Pemeriksaan tidak tuntas & 1 & 3 \\
\hline
\end{tabular}


Penjelasan yang tidak baik atau tidak dipahami pasien, bila muncul kondisi yang tidak diinginkan juga bisa menimbulkan tuduhan negatif atau malah dianggap sebagai malpraktek. Misalnya, sebagaimana responden mengungkapkan:

"Pada saat itu anak saya yang kalau tidak salah baru berumur kurang dari setahun mengeluarkan seperti 'usus' setelah mencret...seperti benjolan di dubur...karena panik dari duburnya keluar sesuatu itu, saya bawa ke UGD..eh...langsung diinfus dan dirawat inap. Kebetulan hari raya, dokter ga ada...dua hari dibolehin pulang, para dokter ga bisa jelasin anak saya kenapa..katanya prolap ususlah, dan lainnya ngomong berbelit-belit tak bisa dimengerti. Trus disuruh rawat jalan..ke dokter anak..dioper ke dokter bedah..ga jelas hubungannya... karenanya saya hentikan, karena sepertinya prosedurnya ga jelas dan dokter-dokter ngga tau atau pura-pura ngga tau apa sebab dan bagaimana penanggulanginya.. yang jelas, semua harus bayar mahal...". (RP30)

"Anak saya yang saat itu demam berdarah pada usia 1 tahun disarankan untuk tinggal, langsung membuka infus tanpa konsultasi terlebih dahulu, menakutnakuti kami sebagai orang tua. Yang mana menurut pendapat saya lebih baik dirawat di rumah dimana dia akan merasa aman dan cepat sembuh, dibandingkan di suasana baru yang akan menambah stres anak dan memperlambat kesembuhan". (RP25)

Secara umum apa yang dipahami masyarakat sebagai malpraktek kedokteran sesuai dengan pandangan ilmu etika kedokteran, yaitu perilaku yang bertentangan dengan prinsip kemanfaatan/tidak memperburuk keadaan, integritas, menghormati hak-hak pasien, dan keadilan. Secara teoritis, responden menilai bahwa malpraktek kedokteran ada unsur kesalahan prosedur dalam pengobatan (22,63\%), tidak sesuai SOP $(22,46 \%)$ ataupun kesalahan dalam diagnosis dan pemeriksaan (16,67\%). Akan tetapi mereka lebih menitikberatkan kepada kondisi akhir pasien tanpa penjelasan riwayat dan perjalanan penyakitnya. Sebagian menilai apa yang dipahaminya sebagai malpraktek kedokteran berdasarkan akibat yang dialami oleh pasien, tanpa melihat tindakan yang telah dilakukan dokter. Meskipun unsure kesalahan prosedur atau pengobatan dipertimbangkan, tetapi yang selalu dititikberatkan adalah kondisi pasien yang menjadi lebih buruk.
Dengan demikian, terlihat bahwa masyarakat lebih mengadopsi nilai filosofis konsekuentialis yang lebih menitikberatkan pada kondisi akhir pasien dan kurang mempertimbangkan prosedur dan tindakan yang telah dilakukan oleh dokter berdasarkan nilai-nilai moral dan standar medis. Sebaliknya, dalam prinsip etika kedokteran, penilaian tindakan sebagai malpraktek kedokteran dilakukan secara obyektif. Kondisi yang buruk setelah dilakukan pengobatan atau tindakan operatif tidaklah dapat disimpulkan akibat kesalahan medis. ${ }^{10-12}$ Kondisi yang memburuk setelah dilakukan penatalaksanaan tersebut perlu dilihat apakah memang telah terjadi kesalahan prosedur penatalaksanaan tersebut yang tidak sesuai dengan standar medis untuk kasus tersebut, seperti obat yang tidak sesuai, dosis yang tidak sesuai, dan efek samping obat akibat tidak adekuatnya anamnesis pasien. ${ }^{11}$

Terdapat kasus-kasus yang menjadi perhatian dokter, rumah sakit, dan petugas kesehatan lainnya, seperti ketidaksiapan alat dan tidak adanya persetujuan sebelum dilakukannya penatalaksanaan. Hal ini tentu perlu dicermati, karena tidak hanya menimbulkan tuntutan malpraktek malah mencerminkan tidak bermutunya pelayanan yang diberikan. Padahal, khususnya persetujuan pasien atau keluarga merupakan langkah sederhana yang dapat mengurangi berbagai tuntutan malpraktek. ${ }^{13,14}$

Akan tetapi, pandangan masyarakat tentang apa yang dimaksud dengan pengalaman malpraktek lebih banyak merupakan ungkapan ketidakpuasannya terhadap pelayanan kesehatan (RP2, 7 dan 8). Masyarakat tidak mengerti tentang penyakit yang diderita serta prosedur tindakan atau pengobatanyang telah dilakukan. Terlihat, dari rangkaian kalimat yang diungkapkan responden antara satu fakta (kalimat) dengan fakta berikutnya, dalam pandangan ilmu kedokteran tidak berhubungan. Hal ini tentu adalah akibat dari rendahnya kualitas komunikasi dan penjelasan yang diberikan dokter sebelum melakukan tindakan tersebut. Akibatnya, pasien berprasangka dan bahkan menuduh kondisi jelek yang muncul setelah itu adalah akibat tindakan tersebut. Pasien tentu tidak punya pengetahuan tentang perjalanan penyakit dan komplikasi penyakit primernya, sehingga bila hal ini tidak dijelaskan pada pasien, dan komplikasi tersebut muncul semasa pengobatan, maka 
tidak terlalu disalahkan apabila pasien atau masyarakat menyalahkan dokter dan pihak rumah sakit.

Begitu juga misalnya, reaksi alergi obat yang menyebabkan bengkak lidah dan mulut bisa juga dituduh sebagai tindakan malpraktek akibat kelebihan obat (RP12). Padahal reaksi ini bisa terjadi akibat reaksi alergi obat, meskipun pengobatan telah tepat dosis. Jika riwayat alergi obat telah ditanyakan dan telah memberikan obat yang tepat, kemudian masih muncul reaksi alergi, secara medis dokter telah melakukan sesuai standar. Jika hal ini tidak dilakukan, tentunya ini merupakan kesalahan dokter tidak menggali riwayat alergi obat sebelum pemberian obat, bukan seperti yang dituduhkan akibat kelebihan dosis.

Pada kasus anak diare dengan keluar benjolan (RP30), terlihat jelas bahwa pasien tidak mendapatkan penjelasan yang cukup terhadap prosedur penatalaksanaan yang dilakukan. Sangat mungkin dokter yang menanganinya menduga kasus ini suspek atau diagnosis klinis suatu prolapsus rektum, yang membutuhkan pemeriksaan yang cermat dan konsultasi beberapa dokter ahli termasuk dokter spesialis anak dan dokter spesialis bedah. Jika hal ini terjadi tentu membutuhkan tindakan operatif. ${ }^{15,16}$ Akan tetapi, karena orang tua pasien tidak mendapatkan penjelasan yang cukup, ia merasa dipermainkan dan menuduh tindakan tersebut suatu malpraktek.

Begitu juga halnya dengan kasus demam berdarah (RP25). Penjelasan yang diberikan dokter dan perawat tidak memberikan pemahaman yang cukup bagi orang tua pasien sehingga ia mengganggapnya malah menakutnakuti. Demam berdarah pada anak, yang disertai gangguan sirkulasi atau telah terjadi syok berat (DBD derajat III dan IV) membutuhkan perawatan, pemantauan serius dan pemberian cairan parenteral (infus). ${ }^{17}$ Orang tua pasien hanya menyangka dengan mengatakan "Menurut pendapat saya" yang mengindikasikan dia tidak diberikan penjelasan yang cukup tentang kondisi penyakit anaknya.

Oleh karena itu untuk mencegah terjadinya tuduhan malpraktek, dokter harus memberikan informasi yang cukup dan dipahami oleh pasien tentang penyakitnya dan penatalaksanaan yang akan dilakukan, serta meminta persetujuan tertulis (informed consent) sebelum penatalaksanaan itu dilakukan. ${ }^{13,14}$ Semua tindakan yang dilakukan tersebut harus dicatat dengan rapi, terlebih lagi jika terjadi pada kasus-kasus yang berisiko tinggi untuk terjadinya tuntutan, seperti di unit gawat darurat. ${ }^{1821}$ Komunikasi yang baik terhadap pasien bisa mengurangi ketidakpuasan pasien terhadap dokter. ${ }^{13,22}$

Ketidakpuasan pasien dan masyarakat terhadap pelayanan yang diberikan dokter dan rumah sakit selalu akan selalu ada. Beberapa tinjauan pustaka menunjukkan bahwa selalu ada perbedaan ekspektasi pasien terhadap dokter tentang apa yang seharusnya dilakukan berdasarkan standar pelayanan medis. $23-24$ Terlebih lagi, tindakan medis membutuhkan dasar ilmu sebelum berbagai tindakan invasif, tindakan diagnostik, medik, bedah dan berbagai pengobatan lainnya dilakukan yang sering kali tidak dipahami oleh masyarakat. ${ }^{25}$

Pemahaman responden tentang malpraktek tersebut umumnya berdasarkan pengetahuan yang didapatnya dari media massa. Bahkan mereka menilai malpraktek banyak terjadi, seperti yang sering dilaporkan di media massa. Dengan demikian terlihat bahwa media massa memegang peranan penting dalam membentuk opini masyarakat tentang pelayanan kesehatan dan isu-isu

malpraktek. Padahal penggambaran isu di media tidak selalu mencerminkan realitas yang sesungguhnya. ${ }^{21}$

Akan tetapi, pemberitaan dan kritisi di media massa dapat mendidik masyarakat untuk meningkatkan kesadarannya tentang hak-hak dan tanggung jawabnya. Hal ini bisa terwujud jika kritisi tersebutdilakukan secara berimbang, karena hubungan profesional dokterpasien adalah kontrak pelayananmedis yang kedua belah pihak harus menyadari akan hak dan tanggung jawabnya. ${ }^{26}$ Begitu juga halnya bagi dokter, keterlibatan media dalam mengkritisi pelayanan kesehatan dapat meningkatkan akuntabilitas pelayanan tersebut secara sosial dan mencegahnya dari kelalaian dan keteledoran (careless and negligence), serta dapat meningkatkan kesadaran mereka akan tanggung jawab profesional dan moral, kode etik, penegakan hukum, dan hak-hak pasien. 27,28 


\section{KESIMPULAN}

Opini masyarakat tentang malpraktek kedokteran sesuai dengan pandangan ilmu etika kedokteran. Masyarakat juga memahami bahwa kesalahan prosedur, diagnosis dan penatalaksanaan merupakan aspek dalam terjadinya malpraktek. Namun masyarakat lebih menitikberatkan kepada akibat yang dialami oleh pasien, yang lebih mengadopsi nilai filosofis konsekuentialis dan kurang mempertimbangkan tindakan yang telah dilakukan oleh dokter berdasarkan nilai-nilai moral dan standar medis.

Beberapa pengalaman masyarakat tentang malpraktek kedokteran terdapat kasus-kasus yang harus menjadi perhatian dokter, rumah sakit, dan petugas kesehatan lainnya, seperti ketidaksiapan alat dan tidak adanya persetujuan sebelum dilakukannya penatalaksanaan. Akan tetapi, lebih umum pandangan masyarakat tentang malpraktek merupakan ungkapan ketidakpuasannya terhadap pelayanan yang didapatkan. Ketidakpuasan tersebut muncul akibat kurangnya komunikasi dan rendahnya kualitas informasi dari dokter atau petugas kesehatan. Oleh karena itu untuk mencegah berbagai tuduhan malpraktek, maka komunikasi yang baik dan pemberian informasi yang cukup mutlak dilakukan sebelum tindakan pemeriksaan dan pengobatan dilakukan.

\section{DAFTAR PUSTAKA}

1. Rogers WA, Braunack-Mayer AJ. Practical ethics for general practice. 2nd edition. Oxford: Oxford University Press; 2009.

2. Häyry M. Utilitarianism and bioethics. In: Ashcroft RE, Dawson A, Draper H, McMilllan JR, editors. Principles of health care ethics. Sussex: Johnson Willey and Son; 2007.

3. Mcnaughton DA, Rawling JP. Deontology. In: Ashcroft RE, Dawson A, Draper H, McMilllan JR, editors. Principles of health care ethics. Sussex: Johnson Willey and Son; 2007.

4. Oakley J. Virtue theory. In: Ashcroft RE, Dawson A, Draper H, McMilllan JR. Principles of health care ethics. Sussex: Johnson Willey and Son; 2007.

5. Jonsen AR. Casuistical reasoning in medical ethics. In: Ashcroft RE, Dawson A, Draper H, McMilllan JR, editors. Principles of health care ethics. Sussex: Johnson Willey and Son; 2007.

6. Sheehan M. Moral relativism. In: Ashcroft RE, Dawson A, Draper H, McMilllan JR, editors. Principles of Health Care Ethics. Sussex: Johnson Willey and Son; 2007.
7. Cullity G. Beneficence. In: Ashcroft RE, Dawson A, Draper H,McMilllan JR, editors. Principles of health care ethics. Sussex: Johnson Willey and Son; 2007.

8. Pemerintah Republik Indonesia. Undang-Undang Republik Indonesia nomor 29 tahun 2004 tentang praktik kedokteran. Jakarta: Pemerintah Republik Indonesia; 2004.

9. Murphy AM. The role of professional organizations in Indonesia's socio-political transformation. NBR Analysis. New York: Columbia University; 2008.

10. Gidwani S, Zaidi, SMR. Birchen MD. Medical negligence in orthopedic surgery: are view of 130 consecutive medical negligence report. Journal of Bone and Joint Surgery. 2009; 91B:151-6.

11. Madea B, Mushoff F, Presuss. J Medical negligegence in drug associated death. Forensic International. 2009; 190:67-73.

12. Varetto L, Cargallo C. Intraabdominal needle: medical malpractice? Forensic International. 2009;191:e11-e13.

13. Kraushar MF. Toward more effective risk prevention. Survey Ophthalmology. 2009; 54(1):150-7.

14. Martinez JA, Lyons JM, O'Leary JP. Medical malpractice matters: informed consent. Journal of Surgical Education. 2009; 66(3): 174-5.

15. Mellgren A, Pollack J, Schultz I. Rectal prolapse, rectal intussusception, and solitary rectal ulcer syndrome. In: Bayless TM,DiehlAM, editors. Advanced Therapy in Gastroenterology and Liver Disease. 5th Edition. Hamilton Canada: B.C. Decker Inc; 2005.

16. Altomare DF, Pucciani F. Rectal prolapse: diagnosis and clinical management. 1st Edition. New York: Springer; 2007.

17. Soedarmo SP. Infeksi virus dengue. Dalam Soedarmo SP, Garna H, Hadinegoro SRS, editor. Buku ajar ilmu kesehatan anak: infeksi dan penyakit tropis. Edisi Pertama. Jakarta: Bagian IKA FK-UI dan IDAI; 2002.

18. Reynard J, Marsh H. Unusual and so unusual ways of ending up in court: how to avoid litigation. British Journal of Urology. 2009; 104:586-9.

19. Kane SM, White RA. Medical malpractice and sport medicine clinician. Clinical Orthopedic and related Research. 2009; 467(2):412-9.

20. Fishbain PA, Lewis, JE, Gao J, Cole B, Rosemoff RS. Alleged medical abandonment in chronic opioid analgesics therapy. Pain Medicine. 2009; 10(4):272-9.

21. Wu CY, Lai HJ, Chen RC. Patient characteristic predict occurrence and outcome of complaints against physician: a study from a medical center Taiwan. Journal Form. Med Assc. 2009; 108(2):126-34.

22. Robbenfolt JK. Apologies and medical error. Clinical Orthopaedic and related Research. 2009;467:376-82.

23. Lin PJ. Criminal judgments to medical malpractice in Taiwan. Legal Medicine. 2009; 11:S376-8. 
24. Rahman MM, Rahman S, Begum N, Asaduzzaman AKM, Shahjahan M, Firoz A, Metul MS. Client expectation from doctors: expectation-reality gap. Kathmandu University Medical Journal. 2007;5(4):56673.

25. Engel E, Livingston EH. Solving the medical malpractice crisis: use a clear and convincing evidence standard. Archive Surgical. 2009;145(3):296-300.

26. Sacapulos M, Segal JJ. Limiting exposure to medical malpractice claims and defamatory cyber postings via patient contracts. Clinical Orthopaedic and Related Research. 2009;467(2):427-33.

27. Sloan F, Shade J. Is there empirical evidence for defensive medicine? A reassessment. Journal of Health Economic. 2009;28:481-91.

28. Taborda JGU, Abdalla FE, Dohler C, Bins HDC. Legal control of the medical profession. Current Opinion Psychiatry. 2009; 22:492-6. 